\title{
Rethinking Western Motu Descent Groups
}

\author{
Michael Goddard
}

University of Newcastle

\begin{abstract}
The Motu-Koitabu are the traditional inhabitants of the site of Papua New Guinea's capital city, Port Moresby, and well represented in a body of literature, from the $1870 \mathrm{~s}$ on, encompassing oral history, archaeology and social anthropology. A basic unit of Motu-Koitabu society is the $i d u h u$, a corporate group which is nowadays conventionally glossed locally as a 'clan' in English, but represented in anthropological literature as more ambiguous in nature than the gloss implies. Considering the literature in the light of recent fieldwork in a Motu-Koitabu village, this article takes issue with an argument developed in the 1950s, which has become an accepted wisdom, that the structure of $i d u h u$ was threatened by the social consequences of missionisation and colonialism, and that $i d u h u$ were saved from collapse by new leaders, church deacons, who replaced traditional leaders.

A re-examination of the nature of $i d u h u$, a partial reinterpretation of notions of leadership and prestige and an account of two recent disputes brought to a village court inform an argument that $i d u h u$ have been more resilient than previous researchers have thought. In this regard concepts of leadership among the Motu-Koitabu need clarification, and it is suggested that the importance of landholding has been underestimated in previous attempts to understand what iduhu are.
\end{abstract}

\section{INTRODUCTION}

Papua New Guinea's capital city, Port Moresby, is built on the land traditionally belonging to two peoples, the Motu and the Koitabu. The Motu were the subject of one of the earliest ethnologies of the region (Turner 1877), and a significant proportion of C.J.Seligman's 1910 volume The Melanesians of British New Guinea was devoted to a description of the Koitabu. Since then a scholarly body of ethnographic, archaeological, oral historical and linguistic works has provided a valuable prehistory and history of the Motu-Koitabu, and of their engagement with a colonial headquarters which grew into a town and then a city. In this article I will revisit this body of work, which I have found invaluable in my own research in Pari, a village on the edge of the city. In 1994 I began a general study of village court procedure at several locations around Port Moresby, including Pari. Understanding village court disputes required me to understand the sociality of the village, and consequently led to research into its history, and aspects of kinship. As my research has continued (the last period was in 1999) I have been considering in particular the nature of the corporate groups, called $i d u h u$ in the Motu language, which Groves described at length in his article 'Western Motu Descent Groups' (Groves:1963).

I want to take issue with a view that has developed from research since the 1950 s on the Motu-Koitabu, particularly in Hanuabada, the complex of villages adjacent to Port Moresby's downtown area. It has been said that the structure of $i d u h u$ was threatened by the social consequences of missionisation and colonialism, and that $i d u h u$ were saved from collapse by new leaders, church deacons, who replaced traditional leaders (Groves 1954, Gregory 1980, 1982). I should make it clear at the outset that I do not dispute to any significant extent the descrip- 
tive contributions of those writers from whose work this view derives. Rather, I offer a partial re-interpretation of available material in the light of my own research in Pari. While my discussion will be circuitous, my conclusions are relatively simple - I believe iduhu have been more resilient than previous researchers have thought, that the importance of landholding has been underestimated in previous attempts to understand what iduhu are, and that concepts of leadership among the Motu-Koitabu need clarification. Since my argument is based on research in Pari, a peri-urban village which has not been engulfed by the growing city as the Hanuabada complex arguably has, I recognise that I might be charged with hasty generalisation. But I hope the reader will be persuaded that the differences between Pari and Hanuabada (in particular that traditional aspects of landholding are handily perceivable in Pari) are advantageous in understanding the nature of Motu-Koitabu iduhu overall. I shall begin with a general discussion of iduhu in the light of past literature, then turn to notions of leadership. The second part of the article turns to the history of Pari village, then to two village court cases whose social context exemplifies salient aspects of landholding in relation to iduhu.

\section{KIN GROUPS AND IDUHU}

Pari is the easternmost of a group of coastal villages in and around the National Capital District inhabited by a traditional people commonly referred to in anthropological and historical literature as the Western Motu. Beyond Pari a bay known as Bootless Inlet divides Western Motu territory from that of the Eastern Motu, who were antagonists of the Western group before European contact. In general references to coastal villages around Port Moresby nowadays it is customary for the inhabitants of the Western Motu villages to be called MotuKoitabu, reflecting a significant degree of intermarriage between the traditionally coastal dwelling Motu and the Koitabu who lived slightly inland. The dominant village cluster of the group, close to the city's downtown area, is popularly referred to as Hanuabada, which means 'Big Village' although it is actually made up of several contiguous villages of which Hanuabada is only one. The Motu language is of the Austronesian group, differs from the non-Austronesian language of the Koitabu, and predominates in the coastal villages.

Oral history and archaeological research (cf. Goava 1979a, Golson 1968, Oram 1968, 1981, Bulmer 1971) suggest that the present sites of the Western Motu villages were established in a series of events following a battle in the 18th century at an ancestral site at the foot of Taurama hill by Kirra Beach (nowadays commonly called Taurama Beach), which is presently part of Pari village land holdings. The ancestral village, Taurama, was said to have been destroyed and its people massacred by the Lakwahara, ancestors of the present Eastern Motu. The sole survivor was a pregnant woman who fled to her natal village, Badihagwa, to the west. She gave birth to a son, Kevau Dagora, who grew to adulthood and then avenged his forebears by leading an expedition by sea and defeating the Lakwahara in war. He subsequently established a coastal village by a hill called Tauata, a short distance from Taurama hill. The village was at first named Tauata but was subsequently called Pari (Motu: wet), allegedly a reference to the villagers' throats being well oiled from eating the plentiful fish there.' During the late 18 th and the 19th century Badihagwa residents moved a short distance to the coast, establishing other villages, where they were joined by Koitabu. According to Koitabu oral history a Koitabu group already living in the vicinity of Tauata joined the Motu at Pari village (Oram 1968:85, 1981:221-226, Goava 1979a:66-67).

Motu oral history holds that migration to the ancestral village of Taurama and its satellite villages like Badihagwa brought together a number of corporate groups, sections of which were subsequently dispersed among the coastal villages. These Motu and Koitabu groups are called $i d u h u$ in the Motu language and their origins, movement, and fragmentation before European contact have been mapped by Oram (1981). In the process of fragmentation the resulting sections of the original iduhu added distinguishing suffixes to the original iduhu name. These sometimes represented fissioned groups as paired opposites (for 
example from classical Gunina iduhu comes Gunina Idibana, or Gunina right side, and Gunina Laurina, Gunina left side). Alternatively, suffixes often linked the new section to a particular location or landmark (for example from classical Kahanamona iduhu comes Kahanamona Idaro, Kahanamona Elevala, Kahanamona Lea Lea). It is not uncommon to find $i d u h u$ with the same classical name and suffix in different villages, but such groups are not regarded as contemporary relatives and are distinguished in conversation, if necessary, by appending the name of their respective villages. Fragmentation and fusion has continued in Motu-Koitabu villages to the present day, with the result that older suffixes have often been replaced with others and in a few cases the classical name may have disappeared.

As can be inferred from the foregoing, the term iduhu refers not only to categories of people in Motu-Koitabu society as a whole, by reference to classical corporate groups, but also to units within villages (for example there are $17 i d u h u$ in Pari village) which result from ongoing movement, fragmentation and occasional fusion. Groves attempted to deal with this terminological problem, in an extensive description of iduhu, by referring to the dispersed classical units as 'clans' and to iduhu within villages as 'sections' (Groves 1963:16). The Motu-Koitabu themselves now translate 'iduhu' (referring to groups within villages) into English as 'clan', reflecting the influence of common, rather than academic, terminology and an idiom that iduhu are principally patrilineal descent groups. Genealogy, with a patrilineal bias, is in fact the ideational factor linking village iduhu to classical iduhu among the Motu-Koitabu, since the ability to trace genealogical links to ancestral figures or iduhu segment founders lends authority to individuals' narration and argument (see, for example Goava 1979a and cf. Oram 1981), and is important in issues such as land claims.

While the main principle of iduhu membership is patrilineal descent, it is possible to become an $i d u h u$ member through prolonged local residence and commitment, as Groves noted (Groves 1963:20-21). Migrants to a Motu village can arrive, for example, as clients of a local $i d u h u$ and over time become accepted as members of that or another iduhu. Similarly, individuals may detach themselves from one $i d u h u$ and commit themselves to another to the point where after a period of time they become accepted as members of the adopted iduhu. Thus while Motu-Koitabu represent $i d u h u$ generally as primarily patrilineal, in genealogical discussions cognatic or affinal elements are commonly included and are not perceived as anomalous. It was this flexibility in recruiting members that prompted Groves to suggest that 'the $i d u h u$ is a political corporation rather than a kin group' (Groves 1963:21). Belshaw, like Seligman before him (Seligman 1910:49), and Groves later, was cautious about using the term 'clan' for $i d u h u$ within villages and differentiated between a clan (which he maintained should consist of people claiming common descent) and an $i d u h u$, which he described as 'primarily a residence unit based upon one or more separate lineages of patrilineal emphasis' (Belshaw 1957:13). Yet he asserted, mistakenly, that village iduhu were exogamous (Belshaw 1957:13). In fact the Motu-Koitabu exogamous group is a cognatic unit, embracing cousins up to about third remove, which crosscuts patrilineal ideation. ${ }^{2}$

The difficulties Belshaw and Groves had in defining iduhu in relation to the concept of 'clan' reflected an issue of their ethnographic period, when anthropology's traditional kinship models were being challenged by findings outside the African context in which the notion of, especially, unilineal clans as exogamous descent groups had been elaborated (Radcliffe-Brown 1967:40, Radcliffe-Brown and Forde 1967, cf. Barnes 1966, Fox 1976:49, Holy 1996:75, Keesing 1975:31). More recent discussion, focussing on disparities between the social practice and idiomatic representations of local groups, has been instrumental in destabilizing lineage models in kinship studies and has acknowledged that earlier analytic categorisations of social groups in relation to Western notions of kinship often did not reflect indigenous conceptualisations (Schneider 1984:187-201, Holy 1996:90-101).

Both Belshaw and Groves attempted to find a tidy set of criteria typifying iduhu. Belshaw, working in Hanuabada, used residential unity, possession of a ceremonial platform 
or verandah and exogamy as the defining criteria (Belshaw 1957:13). Groves commented that there were iduhu which fulfilled none of these requirements, and proposed instead a dozen 'assets' which iduhu might ideally possess, but of which in reality an iduhu may lack one or another. These included a name, a heavy fishing net, equipment to build trading vessels, a residential locality, privileged claims to particular dances, sacramental relationships with ancestral deities, exogamy and bridewealth, food distribution at feasts, garden land, a labour force, a leader, and a corporate history (Groves 1963:18). These attempts to define iduhu are notable for the lack of primacy, or even significance in the case of Belshaw, given to land possession. Groves observed that not all $i d u h u$ were 'land-owning' units, nor were all land-owning units $i d u h u$, and Motuan assertions that cognatic descendants of an original cultivator could claim cultivation rights in a plot under the management of the genealogically senior agnatic descendant led him to conclude that 'Motu ideology concerning land tenure provides for continued managerial control in the absence of agnatic heirs' (1963:26-27).

In marked contrast to Belshaw and Groves, post-colonial indigenous writers have prioritized landholding in defining $i d u h u$ at village level. An iduhu was 'the largest body of people who may interest themselves in a piece of land as a whole' according to Diritala (1976:58), and a short account of land tenure in Hanuabada in 1978 by a Motuan situated matters concerning land - 'the most important property owned by the people' — firmly in the context of iduhu (translated as 'clan') and bese ('lineage') membership (Tau 1978:75-84). Diritala's definition of an iduhu was reproduced by a Hanuabadan writer, Sinaka Goava (Goava and Wrondimi 1986:4). Further, Diritala, Goava and Wrondimi described iduhu membership, rights and inheritance almost exclusively in relation to matters of landholding. Grove's observations about cognatic and affinal rights in iduhu are confirmed in these indigenous discussions (Diritala 1976:59-65, Goava and Wrondimi 1986:4-5, 22-25). Iduhu are described as primarily patrilineal, with headship inherited usually by agnatic primogeniture, but with flexible criteria in recruitment. This flexibility is prefaced in the account of Goava and Wrondimi by an assertion that the modern complement of $i d u h u$ 'does not purely reflect that of the traditional clan system. Today the composition of clans is not strictly of close family members but a mixture of families from different clans within the village or from outside the village' (Goava and Wrondimi 1986:4). The authors attribute the current situation, slightly confusingly, to the emergence of intermarriage between different clans and outside the clan' (Goava and Wrondimi 1986:4). Diritala is more circumspect about claims of former exclusivity (Diritala 1976:66-67), and indeed the suggestion that $i d u h u$ were traditionally more exclusive in composition, or more resistant to marriage with outsiders, is not borne out by accounts from the early colonial period (e.g. Seligman 1910, Goava 1979a) or research into that period and recent prehistory (e.g. Oram 1968, 1981, Dutton 1985:149-194). It is likely that early iduhu had core patrilineages through which hereditary leadership passed, but that recruitment was otherwise flexible.

The indigenous exegeses cited above emerged in a climate of growing Motu-Koitabu concerns since the end of the colonial era about the growth of Port Moresby. The development of the city has resulted in increasing loss of traditional land through infrastructural installations, the construction of modern office and shopping complexes and the spread of suburban housing. These and connected issues such as indigenous reassessment of the nature of early land 'purchases' by the colonial administration, the pursuance of compensation payments for land loss and concern about the growth of the migrant population were not as evident, or at least not being so clearly articulated, in the 1950s and 1960s when Belshaw and Groves conducted their research and Port Moresby was still a small Europeancontrolled town. The Hanuabada villages discussed by Belshaw and Groves were affected by the infrastructure of Port Moresby from the late 19th century. Missionaries, administrative officials, traders and urban service providers were well established on Hanuabada land by the 1950s. The ethnographic methods and descriptive focus of Belshaw and Groves may 
not have provoked indigenous disclosure of the importance of land in iduhu affairs at the time. More revealing, in this respect, are references to migrant Papua New Guineans in Port Moresby after the war negotiating with Motu-Koitabu landholders, rather than the Administration, for permission to establish settlements (e.g. Oram 1976:98ff, 184ff, Norwood 1984:passim, Hitchcock and Oram 1976) and of the vexed dealings of the administration with increasingly vigilant landholders who were becoming alarmed at their apparent loss of land in the later colonial period (Oram 1976:175ff). By the end of the colonial era urban Motu-Koitabu had become well aware that land occupation by outsiders no longer manifested a basis for ongoing relationships of negotiation and exchange, as it once had, but amounted to real land loss. New waves of settlers did not ask their permission to establish habitats around the city, and the administration negotiated town planning programmes as if simple large money compensation payments were adequate transactional responses to 'local landowners'. The rhetoric of recent Motu-Koitabu concerns about land loss indicates that they continue to see themselves as the landholders of the city area (Kidu 1999, Sefala 1999, Joku 1999), and regard this as fundamental to their corporate identity.

As the comments about marriage tendencies (above) suggest, some indigenous writers' assertions about the past are contestable, and susceptible to argument that they are discourses which creatively interpret tradition in the context of contemporary political exigencies (cf. Hanson 1989, Turner 1997). However it would be unwise to assume that the indigenous definitions of iduhu specifically as landholding groups are simply an 'invention' of tradition to serve contemporary land claims. The only corporate groups existing among the MotuKoitabu in oral or written historical accounts have been iduhu. Although the term bese was translated by Tau as 'lineage' (Tau 1978), it is actually used ambiguously for descent groupings of various size from family to the Motu as a whole. ${ }^{3}$ The groups which migrated to Taurama, and subsequently to new sites, in the classical era were $i d u h u$, and these must have been the units which took possession of land in their new habitats. When a new iduhu arrived in an existing village its members quickly moved to negotiate gardening land, in the first instance, and then to consolidate their holdings. Examples later in this discussion will show that failure by an $i d u h u$ to achieve these ends reduces its members to a tenuous social existence in a village. While an iduhu might at any given time be landless (Groves 1963:26), an important condition for the survival of an iduhu over time is possession of land. In view of these considerations it is not surprising that when indigenous writers seek to define $i d u h u$ in brief, landholding is mooted as a primary criterion.

\section{LEADERSHIP AND LOHIA}

While the markedly flexible criteria for $i d u h u$ membership suggest filiation is not a paramount issue, Motu-Koitabuans demonstrate a robust genealogical memory. I have found, for instance, that middle-aged people in Pari can commonly recount descent without hesitation through seven or eight ascending generations. Further, lineage and iduhu leaders are important points of reference in local discourses of iduhu. The inheritance of leadership through agnatic primogeniture and the strength of genealogical memory suggest that investigating leadership may be analytically useful in understanding the concept of iduhu. But the notion of leadership itself has proved as vexed for researchers as that of iduhu. In 1877 an ethnologist wrote:

Every village possesses a certain number of lohiapata or chiefs, one or two being generally a little more important than the rest. The chieftainship descends from father to son. The distinction between these chiefs, and who they are chiefs of, we cannot yet determine. These chiefs as a rule possess little or no authority and have little power in quelling a disturbance. They are however consulted in any matter affecting the interests of the village. (Turner 1877:53) 
It is clear from oral historical accounts and from Turner's failure to perceive immediate and significant political distinctions between 'chiefs' and commoners that before colonization Motu-Koitabu territory did not constitute a chiefdom - 'a regional polity with institutional governance and some social stratification' (Earle 1997:14) — in any form recognised by anthropological convention (see, e.g., Wolf 1982:96). The degree of political authority which Turner sought in 'chiefs' was rare among traditional Melanesian societies, where elements of social control were embedded in kinship and exchange relations, sorcery and the sanctions of tutelary spirits, rather than centralised in individual political leaders. But certainly there were men regarded as community leaders among the Motu-Koitabu. Seligman, writing primarily on the Koitabu, referred to leaders as rohi (which he translated as 'chief' or 'headman'), and described their duties mostly in terms of directing ceremonies and feasting and, in a brief mention, dealing with land questions (Seligman 1910:52-58). He believed the colonial appointment of village constables who acted as 'government chiefs' affected traditional leaders' authority: 'At the present time the influence of the iduhu rohi and rohi ketaike [Koitabu: village headman] is necessarily diminished... In many matters, however, the old men still continue to play a prominent part, their advice is usually sought and taken, and their directive obeyed' (Seligman 1910:58).

The view that 'traditional' leaders have been replaced by other types of leaders was also expressed by Groves (1954), and more recently by C.A.Gregory (1980, 1982), referring to the influence of the London Missionary Society (which dominated the Papuan coast in the early colonial period) and its successor, the United Church. According to Gregory, the United Church had a great transformational influence on Motu villages, particularly Poreporena village close to downtown Port Moresby, suppressing the traditional gift exchange system and usurping the power of traditional leaders. 'They have been replaced by church deacons, the "neo-big-men" of the new gift exchange system that has been established by the church in order to raise money. It was the rise of these men that saved the clan (iduhu) system from collapsing.' (Gregory 1982:206 and cf. 1980:630). Gregory describes the deacons as 'subclan' leaders elected by the members of their subclan. He dates the establishment of church donation competitions, known as bou bou and largely responsible for funding churches, as having been 1948 at Poreporena village when a church pastor instigated a fundraising competition with a flag as a prize. Competition both between deacons and between clans is said to produce a ranking of deacons and clans (Gregory 1982:206-7 and 1980:630-634). The highly competitive aspect of bou bou may be a post-war phenomenon, but it should be noted that the church collections themselves were introduced in 1889 by the LMS, and nearly all Motu village churches were financially supporting their own pastors by 1919 (Oram 1989:66). Oram points out that before the Second World War church organisation was based on the iduhu, which retained its importance, and that men who achieved leadership in new situations gained support from kinship and other traditional bases. (Oram 1976:61)

Gregory's contention that the rise of church deacons saved the iduhu system from collapsing has a thematic precedent in an article by Groves in 1954 which discussed the Christian suppression and subsequent decline of Motu dancing in Poreporena village, the colonial introduction of a village council, and the disappearance of associated activities such as feasting: 'The iduhu structure was still quite apparent in the 1930s, but its foundations were steadily being eaten away' (Groves 1954:86). Drawing attention to the integration of church organisation into extended kingroup organisation, Groves linked the survival of iduhu to elected church deacons 'whose power in the village clearly draws much of its force from the iduhu structure' (Groves 1954:87).

In view of the contention that there are new types of leaders some clarification of Motu notions of leadership and authority is required here. The Motu term most commonly (though often cautiously) translated as 'chief' by researchers is lohia (Turner 1877, Seligman 1910, Belshaw 1957, Groves 1954, 1963, Oram 1968, Dutton 1982). Motuans themselves translate lohia as 'chief' when asked, untrammelled by anthropological uncertainties 
about the analytic usefulness of the latter term (e.g. Wolf 1982:96-99, White 1992, Scaglion 1996). In modern Papua New Guinean English the terms 'chief' and 'big-man' (another anthropological vexation) are often used interchangeably in urban Papuan conversation, and are not (for my enterprise here, at least) analytically useful as interpretations of indigenous language terms. The proliferation of 'chiefs' and 'paramount chiefs' in recent years in Melanesia has been humorously noted by Filer in compilations of news items (Filer 1994:85-92, 1995:19-20), and addressed as a problematique by a number of writers. Among these, White has contextualised the modern notion of chiefs in Pacific countries in the interplay of creativity and continuities informing perceptions of 'custom' in cultural reproduction: 'Even brief consideration of local discussions of chiefs reveals complex and competing views of the role of perceived custom in constituting the status of "traditional chiefs" (White 1992:77). Accordingly it has been argued that, rather than a focus on political types, the study of discourses that 'work to construct, validate, and empower local leaders as traditional or customary' (Lindstrom and White 1997:6) would be fruitful. Given the generalization that Pacific leaders who claim traditional authority nowadays are commonly called 'chiefs', Lindstrom and White use the term to designate 'a political leader who draws his authority and influence from a discourse of local tradition' (1997:10).

However, as such a conception capitulates to the indigenous adoption of English lay usage of the term 'chief', and does not appear to take account of non-discursive factors in the social context of particular and localised forms of leadership, I do not find it useful in trying to understand leadership in Motu-Koitabu society. More helpful in this case is Wolf's suggestion, made in a discussion of the uses of the concept of mode of production, that consideration of 'chiefs' should involve an inquiry into the ways social labour is deployed (Wolf 1982:97). In particular, Wolf says of chiefs in kin-ordered (as distinct from tributary) societies, that they are embedded in, and bound by, kinship arrangements (ibid.), and that

The kin-ordered mode inhibits the institutionalization of political power, resting essentially upon the management of consensus among clusters of participants. Moreover, the ties of kinship set limits to the amount of social labour that can be mobilized for collective purposes....A chief can become a pivot of the power of his kinship group; but if he is sometimes able to incarnate the kin order, he is also its prisoner. (Wolf 1982:99)

Bearing these comments in mind, some distinctions should be noted in types of leadership and authority among the Motu-Koitabu.

As well as the general term lohia, other terms of authority noted by Groves (1954:80-81, 1963:19) such as biaguna (boss, pl. biagudia) and kwarana (from kwara: head, pl. kwaradia) are still common in Motu. An iduhu leader can be spoken of as an iduhu biaguna or an iduhu kwarana, and a land controller as a tanobiaguna (tano: land). In the days of the hiri - long-distance trade expeditions by sea to the Gulf district, discontinued in the early twentieth century - a voyage's organiser was known as a baditauna (badina: source or cause, tau: man) and his seconder as a doritauna (etymology obscure ${ }^{5}$ ). These were not necessarily $i d u h u$ leaders, and Oram states that sometimes $i d u h u$ leaders would be crew members (Oram 1982:13). Also, in times before missionary censure destroyed traditional dancing, a festive dance could be instigated not only by an iduhu kwarana, but also by other senior males in the $i d u h u$, with the permission of the iduhu kwarana (Groves 1954:80, 82), thus providing an opportunity for the achievement of renown through a spectacularly successful dance ceremony representing an iduhu's resourcefulness. There were, then, opportunities in the past for men to achieve high status without being a hereditary iduhu kwarana, which appears to confirm Oram's observation (1989:73) that a distinction can be made between hereditary, ascribed, status and achieved status among the MotuKoitabu. ${ }^{6}$ But some qualification is necessary in respect of ascription. 
In the case of hereditary status, the observance of agnatic primogeniture in the inheritance of $i d u h u$ leadership is sometimes breached when an ageing iduhu kwarana has no son or when a son is too young or (in rare cases) refuses for some reason to accept the responsibility of leadership. In such cases leadership is usually passed to a younger brother of the former leader. If a son is passed over because of his youth or immaturity, he can make a claim for the leadership at a later time. Also, the leader may choose to delegate authority in some matters to others. For example, an iduhu kwarana is usually the iduhu tanobiaguna (land controller), unless he chooses to hand this duty to another senior male in the iduhu. In respect of the term lohia, my findings in Pari confirm Groves' observation (based on research in Manumanu and Poreporena) that terms such as iduhu kwarana and iduhu lohia are to a degree interchangeable, but sometimes refer to two different individuals - a distinction between a hereditary leader and a person of non-hereditary high status. I agree with Groves' view that the language allows a clear distinction to be drawn between formal status and de facto power and, importantly, that a non-hereditary iduhu lohia could break away and begin a new iduhu of which he would be kwarana (Groves 1954:80-81). The latter case has in fact occurred in Pari village in recent years, and indicates that the achieved/ascribed leadership distinction should be applied cautiously, since there are situations where a non-hereditary leader (i.e. of a new iduhu), can be succeeded by a hereditary one (his son). Like the occasional breaches of strict agnatic primogeniture mentioned above, it demonstrates an apposite point made by Douglas (citing Goldman 1970) that while ascribed and achieved status can be distinguished from one another in abstraction, historical reality is ambiguous (Douglas 1979:4).

In the modern world of the Motu-Koitabu, business success, high rank in public-service employment, and success in provincial and national politics can also bring men recognition and deference in village society. These men can be referred to as lohia (I have never heard the term applied to a woman) particularly if their power is seen to be used for the benefit of their own people, that is to say, if their position in the integration of village society with capitalist society and its administrative bureacracy has been advantageous to their group and not just to themselves. In Pari people distinguished in casual conversation with me between hereditary leaders who were assertive and others who were seen as relatively inactive, but the term lohia tends to be used of all hereditary leaders as a matter of respect. Oram regarded the translation of lohia as 'chief' as equivocal, given the lack of apparent figures of authority at village level and noted that 'Lohia could be applied to heads of descent groups, who performed important ritual functions, and also to any man of eminence, including war leaders, leaders of trading expeditions etc' (Oram 1968:84fn). Taking into account the above distinctions in types of leadership, authority and status, and the convergences manifest in the use of the term lohia, applied both to hereditary leaders and to those who achieve high social status through various exploits, lohia is best interpreted for analytic purposes to mean a venerable man or man of renown, rather than a chief or headman. ${ }^{7}$

The disappearance of the ceremonial feasts and distributions described by Seligman (1910:142-150) and of the dances discussed by Groves (1954) certainly meant that some manifestations of the ability of hereditary iduhu kwaradia to mobilize social labour for collective purposes (see Wolf 1982:99) disappeared. But whether this constituted a lessening of their primary authority and power, and whether it undermined the structure of iduhu, is debatable. With the passing away of a number of traditional activities men who were not hereditary leaders had to explore other ways of achieving renown (of becoming a lohia, according to the indigenous meaning I have suggested), among them church offices, business opportunities, the public service and politics. But prominence and fame in these activities can be shortlived. Meanwhile hereditary leaders are assured of ascribed status and of their place in authoritative genealogies grounded in the classical age of their society (the 18 th century) and reproduced with every new generation. To this extent a hereditary leader certainly does 'incarnate the kin order', in Wolf's terms (1982:99).

Since recruitment to an $i d u h u$ is not dependent on patrifiliation, and can be achieved at 
the least through residence and social commitment, patrilineage must be analytically approached as more idiomatic than biologically primordial when considering the conceptualisation of iduhu by the Motu-Koitabu. In this respect the iduhu kwarana is positioned not as a political figure of the type early ethnologists sought in chiefly men, but as a personification of the idiom through which the $i d u h u$, as a political corporation, expresses its identity. This identity is necessarily historical, and so the kwarana, whose position is inherited (in principle) through agnatic primogeniture, becomes central, incarnating the particular genealogy linking a contemporary $i d u h u$ to at least the classical period (the 18 th century). In other words, he incarnates the ancestry of the $i d u h u$. The authority of the kwarana lies in his symbolic polyvocality: he represents the living $i d u h u$ to other groups and to the ancestors (this used to be manifest in his facilitation of feasting and dancing, for example - cf. Oram 1989:50), and importantly, he represents the ancestors to the living iduhu. This latter aspect of the iduhu kwarana has not been given adequate attention in previous discussion: it can be partially exemplified by the following account of an incident during my fieldwork.

In recent years Pari village has revived a colonial institution, the village clean-up day, to deal with the advent of large and bad-smelling rubbish piles around its houses and gathering places. Rubbish piles are common in Port Moresby, and increasingly in rural communities, resulting from the arrival and overwhelming increase in plastic and tin containers and non-biodegradable products in societies accustomed to tossing away innocuous natural materials. The National Capital District has a rubbish collection service, but it is unreliable, and peri-urban villages are even more bereft of its visits than suburban areas. The colonial village clean-up day began with a blast on a whistle from a patrol officer, whereupon the villagers would briskly tidy their habitat. The revival of this practice, with a senior villager as whistle-blower, has proved successful in Pari, and is carried out several times a year.

Early in 1999, when it was time to conduct a village clean-up, the retired 'village leader' (hanua kwarana) died. He had been the iduhu kwarana of Idibana Taulamiri iduhu, which was the senior iduhu of the village by virtue of its direct patrilineal links to the founder of Pari, Kevau Dagora. He was no longer the active head at the time of his death as some years previously, with advancing age, he had passed on his iduhu headship to a younger brother, his own eldest son being unready for the responsibility at the time. When he died the village went into a period of mourning, ritually involving the cessation of all non-essential activities in the village area (people employed in town still went to work). The conventional period of mourning in such cases is four weeks. Senior village men immediately declared the clean-up day postponed till after the mourning period, but many villagers felt the village should be cleaned as the rubbish and the smell were increasing steadily. Under pressure, the seniors (badadia) relented, and with one week of mourning still to go, a clean-up day was begun. However, when the whistle was blown a massive thunderstorm ensued. At this sign of ancestral displeasure, the clean-up was abandoned, to be conducted only after the full mourning period had passed.

What makes this episode apposite to an understanding of the authority of 'traditional leaders' is that the man who died was no longer actively the village leader, having passed on his title, and had by all accounts had a low social profile during his headship, yet elemental forces were unleashed on the villagers for disrespect. Political activity or renown is not an issue here, the authority of the hanua kwarana comes from his embodiment of village history. The clean-up attempt indicated disrespect not only to the dead man, but to an ancestry stretching back to the village founder, Kevau Dagora. If the authority of traditional 'chiefs' was not engendered by socio-political achievement, we cannot say with confidence that their traditional powers have been usurped by new (non-hereditary) leaders. Rather, it is likely that those powers are simply veiled by new discourses privileging the public achievements of church leaders, businessmen and politicians in the engagement of Motu-Koitabu with the institutions of the modern state. It remains, though, to address the related question in the academic literature of whether the survival of $i d u h u$ as an institution is really due to 
new forms of leadership (Groves 1954:86-87, Gregory 1980:630, 1982:206). I hope to achieve some clarification in the remainder of this paper, by turning to the history of Pari village and its $i d u h u$, and to two disputes brought to Pari's village court.

\section{PARI VILLAGE AND IDUHU HISTORY}

In 1904 Seligman drew a plan of Pari, plotting 58 dwellings (Seligman 1910:46). ${ }^{8}$ The village contained possibly 400 people at the time. During the Second World War, by which time the population had grown to almost 600 , it was evacuated, like most of the Western Motu villages (Robinson 1979:101-110, Tarr 1973) and some able-bodied men were taken to work for the Australian military. The period was not only socially disruptive but took a mortal toll as a lack of gardening resources and poor nutrition at their evacuation site $^{9}$ made the villagers vulnerable to illness. When they returned at the end of the war they numbered only 477 (Tarr 1973:22). The village itself had meanwhile been looted for timber and garden produce and had to be substantially rebuilt (Tarr 1973). A map by Maddocks in 1974 shows more than 100 dwellings (Maddocks et al. 1974), and he noted in 1971 that the population seemed to have increased 'from about 400 persons in 1910 to about 650 in 1961 ' (Maddocks 1971:6). In 1969 a census calculated 937 residents (Maddocks and Maddocks 1972:225). By 1990 according to census figures this had increased to just over $2000 .{ }^{10}$ The village is relatively affluent, by virtue of its long contact with missionaries and associated educational institutions and proximity to Port Moresby. Most adult males and roughly $20 \%$ of women are in wage employment (cf. Maddocks and Maddocks 1972:227), and a number of men occupy high status public-service positions in the city. The population of Pari village, like those of other Western Motu villages, is not exclusively Motu-Koitabu; there is a significant presence of intermarrying migrants mostly from the Gulf District (grounded in the relations established by 19 th century hiri trading expeditions). Further, house by house genealogical data collected by Maddocks and others in 1974 show that non-Papua New Guineans (mostly European) have lived in, and occasionally married into, Pari village for some decades, although not in great numbers (Maddocks et al. 1974). But Pari remained a fairly insular community by the 1990s (by which time the European presence had all but disappeared) despite being at the edge of the city.

Traditionally the villagers made pots for trade (Bulmer 1982:122) and Pari was one of the Western Motu villages involved in the hiri, the pots-for-sago trade voyage to communities in the Papuan Gulf last century. Historically, however, the identity of Pari as a community was grounded in its specialisation in tuna fishing, chartered by the kidukidu (Motu: yellowfin tuna) legend of the village in which a woman called Ugata ${ }^{11}$ Vaina secretly gave birth to five tuna, of which one was subsequently killed in ignorance of its parentage by her husband (Kidu 1976, Pulsford 1975:107-108). Tuna fishing's preparatory and attendant rituals once took up a large part of the year, but declined significantly during the colonial period (Pulsford 1975). In the late 1990s some villagers still moved to nearby Oyster Bay (where Ugata Vaina gave birth to kidukidu) to camp and fish during the tuna run from May to September, but with little more ritual preparation than Christian prayers for a good catch.

The centre of Pari is dominated by a large and immaculately kept church, representing the United Church, successor of the London Missionary Society. It was built with the proceeds of the church donation competitions known as bou bou (Motu: offering, sacrifice). Pari villagers divide into 51 small groups for the purposes of bou bou, each group led by a church deacon. Unlike the 'subclan' grouping which Gregory reports for Poreporena (Gregory 1980:630-634, 1982:206-207), the small groups in Pari, while arrived at by subdividing $i d u h u$, are not genealogical sub-iduhu, but are small equal-sized groups of families providing manageable and equal constituencies for the deacons. Further, the deacons are assigned to their subgroups by lottery, meaning that it would only be by chance that a deacon would lead a group from his own $i d u h u$. It can thus be seen that the structural relationship of the office 
of church deacons to iduhu in Pari is of a different order to that of hereditary leaders (iduhu $k w a r a d i a)$. While the church has historically been socially institutionalised in Motu-Koitabu society through its integration into the $i d u h u$ system, and men who become church deacons draw political support from kinship networks (as do most people in non-hereditary public office in Melanesia), I could not confidently infer from my observations at Pari that the rise of church deacons had 'saved' the iduhu system or was a necessary condition of its survival.

Oral history within Pari village endorses the general Motuan account of a dispersal from the ancestral village at Taurama and intermarriage with Koitabu. As stated earlier, the establishment of villages on the coast following the 18th century massacre at Taurama meant sections of the iduhu attested to have been at Taurama were propagated in the new villages. Kevau Dagora, founder of Pari, established an iduhu retrospectively called Idibana as the first $i d u h u$ of the village. The second $i d u h u$ is said to have been Kahanamona. In the 18th century a section of the classical Kahanamona iduhu lived at a place called Idarobada, a short distance away from the main Taurama village, and escaped the massacre. According to most oral historical accounts Vagi Boge, husband of Ugata Vaina, the woman who gave birth to tuna, belonged to this group and brought it to join Kevau Dagora at Pari. The two iduhu are said to have divided the main beach area between themselves, Idibana building their houses over the water to the east (or left, facing the sea), and Kahanamona to the west. Gardening areas were established by the same principle. As other iduhu subsequently joined them, they were permitted to build houses in lines over the water in both halves and were given garden land by the original leader.

When Seligman plotted the village in 1904 (more than a century after its establishment) he found eight iduhu roughly in sequence along the beach, with Kahanamona house lines at the western end, Idibana at the eastern end, and six other iduhu arranged between them. By the mid 1990s there were $17 i d u h u$, resulting from segmentation and the arrival of groups from other areas. For example, due to segmentation there were now four 'Idibana' iduhu, Idibana Taulamiri, Idibana Laurina, Idibana Rarua Mase and Idibana Etau Laio. Arrivals during the century included, for example, Kahanamona Elevala and Kahanamona Lea Lea. These two groups derived from the classical Kahanamona iduhu by geographical segmentation in previous centuries and as a consequence of their incorporation into the village Pari's original Kahanamona group became distinguishable by the name Kahanamona Idaro.

As generations went by the gardening land apportioned to villagers, originally claimed by the first $i d u h u$, became conventionally recognised as belonging primarily to those iduhu whose members had continuously utilised it over a long period of time. While land was inherited patrilineally and usually by males, a woman could be given land by an agnate (her father, usually). Also, people without land (for example migrants from the Gulf district and elsewhere) could acquire gardening land by negotiation with landholders or by marrying into a local $i d u h u$ and gaining access by way of their spouses' rights. Newcomers joined the household of their spouse, or were given permission to build houses on allotted sites. After the Second World War (during which most houses had been destroyed), as the village reestablished itself and grew, houses began to be built on the land, often sited on the territory (established by continuous usage) of the iduhu of the male household head. However, as patrilocal post-marital residence is not a rule but a tendency, house sites were often negotiated through affinal or cognatic links. The result is that in modern Pari, while some clusters of land-houses represent a definite grouping of iduhu members on their own territory, overall the location of households in the general on-land village area cannot be taken as a guide to $i d u h u$ territories.

While Pari could be reasonably described as a peaceful village, where disruption occurs only in the form of noisy drunkenness of a few men at weekends, there is an undercurrent of chronic dispute over landholding as people seek to build new houses or develop new gardens. Many of these disputes are managed through negotiation, involving meetings of iduhu kwaradia and elders (badadia), in which genealogical testimony and memories of 
earlier apportionments, negotiations and agreements contribute to a settlement involving elements of mediation and arbitration. Older villagers speak of this ongoing friction as if it were a postwar phenomenon - the evacuation and rebuilding of Pari is discursively positioned as a loss of an earlier, tidily ordered, landholding system and the onset of disarray. As these older people were children when the village was evacuated it is difficult to judge the veracity of their representation of the earlier era of landholding. In discussions of rights to land which I heard, old men told not only of their own remembered arrangements regarding particular areas, but drew on handed-down accounts of previous negotiations, going back several generations. Whether these accounts were accurate or merely self-serving in their specificity, they suggest that while in the past iduhu kwaradia or tanobiagudia may have been the final authority on landholding, negotiation has always been prevalent among individuals over gardening and other rights. In this respect Motu-Koitabu demonstrate a system of land holding and rights, involving the negotiation of multiple differential claims, which fits common generalisations in academic representations of customary land holding in Papua New Guinea (e.g. Hogbin and Lawrence 1967, Sack 1973:19-46, Zorn 1992:5-7).

In modern times failed negotiations, and contention over gardening, residential and other access to local land are sometimes components of disputes taken to Pari village court. Village courts are an institution established by legislation at the end of the colonial era. Their magistrates are not legally trained, but chosen from local communities, usually by the members of those communities. The courts are intended to deal with petty local disputes, following custom where possible, and are not allowed to hear major land disputes (these go to a land court), but they can hear disputes over gardens, trespass, and other matters to do with locally understood rights and obligations in relation to land. The two cases discussed below, both occurring in 1999, reveal important aspects of kinship, iduhu membership and land rights in Pari, and exemplify a number of points developed earlier in this paper.

\section{THE SIMPSON CASE}

At the centre of this dispute were three women related by birth, Janet, Mary and Anna (not their real names ${ }^{12}$ ), who were married to non-Pari men. Mary and Anna and their husbands had negotiated permission about ten years previously to live on land controlled by a senior village man, being themselves landless for reasons which will be discussed later. Mary was married to Tom, a man from another part of the country (hereinafter called 'Gabuamo'), and had lived at other locations around Port Moresby as Tom moved from job to job. This was their chance to settle. The tanobiaguna (land controller) gave his approval for them to bring other people to live with them on the condition that all parties lived peacefully and looked after the land. Mary and Anna invited Janet to establish a house next to theirs. Janet was married to Tom's sister's son, Jack, from Gabuamo. Jack, like Tom, had been living at various locations around Port Moresby until now. At first the neighbourly arrangement worked satisfactorily but gradually friction developed between the two households, and eventually Mary and Anna decided that Janet and her husband had to go. Things came to a head when, without consulting the tanobiaguna, they gave Janet and Jack one week to leave and informed them a bulldozer would subsequently arrive to level the area they were occupying. Janet and Jack worked frantically to dismantle their stilt-supported house, but when the bulldozer arrived the houseposts were still in place, and these and some plants and gardens were casualties of the subsequent levelling of the area. In distress Jack got drunk, damaged water tanks, plants and other property of Mary and Anna's household, and punched the two women. Hence the two parties came to village court accusing each other of damage and claiming compensation of several hundred kina each.

As a village court hearing, the procedure of the case and its outcome were unexceptional. The property damage suffered by both sides was carefully itemised and costs were added up and agreed to. The case was then adjourned for one week for the parties to consider 
whether they were reconcilable so far as future cohabitation was concerned. The following week Janet, speaking for herself and her husband, said they had moved to another location in Pari territory, and would not consider trying to return to the area where Mary and Anna lived. During this statement to the magistrates Janet commented, in an audible aside to Mary and Anna 'If I leave, then you will leave'. The import of that aside was not clear to me at the time, but would prove to be significant in the wider social and historical context of the case. The remaining issue for the court was to decide on the compensation to be paid. The property damage claims were found to be roughly equal in financial measure, and cancelled each other out. It remained for Jack to compensate Mary and Anna for assault. He was ordered to pay each of them $\mathrm{K} 100$, and the case was closed.

Immediately after the hearing, the last for the day, there was some discussion among the magistrates and the tanobiaguna which contextualised the dispute in wider social issues. The magistrates were lamenting the disruption to landholding arrangements and rights when foreigners moved into the village, became partially absorbed into local social and political structures, and then departed, leaving descendants with equivocal rights. I learned that two of the three women were adoptees, and all three of them were descendants of a foreigner. The magistrates were concerned about the future prospects of Mary and Anna, neither of whom (the magistrates said) belonged to an iduhu even though they were brought up in the village. Some genealogical elaboration is necessary at this point, to better understand the social context of Janet's dispute with Mary and Anna.

Mary, Anna and Janet were descendants of 'Paul Simpson,' who was one of more than a dozen children of a foreigner who arrived in Port Moresby late in the 19th century. Paul Simpson's father had married a Pari woman, of Idibana iduhu, who was working as a domestic servant in a European household. They had lived some distance from Pari, and the marriage had not introduced the man into Pari society. At the turn of the century and for much of the colonial period, the children of such marriages were labelled 'mixed race' (the term is still used in modern PNG) or 'half-caste' and were commonly marginalised in colonial European society and unwilling or unable to immerse themselves in indigenous society. Paul Simpson himself married a woman described to me by older Pari people as a 'South Sea Islander' (a term they often apply to Polynesians) and had eight children, of whom Mary was the last born. In the $1960 \mathrm{~s}$ - as Port Moresby was growing rapidly and the cash economy was well established in nearby villages - the Simpson family, including the aging Paul and two adult sons, opened a trade store in Pari village. They were given permission to reside and operate their store on land belonging to Idibana iduhu.

Several of Paul Simpson's daughters were married to Australians and Anna was the

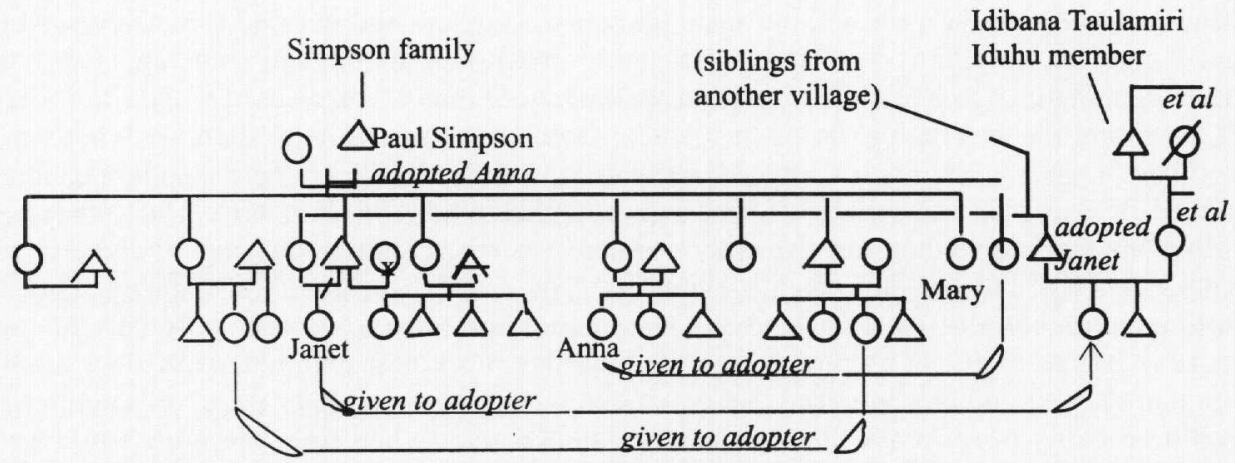

Figure 1. Simpson family in Pari: genealogy and marriages to about 1970. (Sources: Maddocks et al. 1974 and oral testimony Pari village 1999). NB: All marriage partners of Simpson descendants are nonPari villagers except for $x$. 


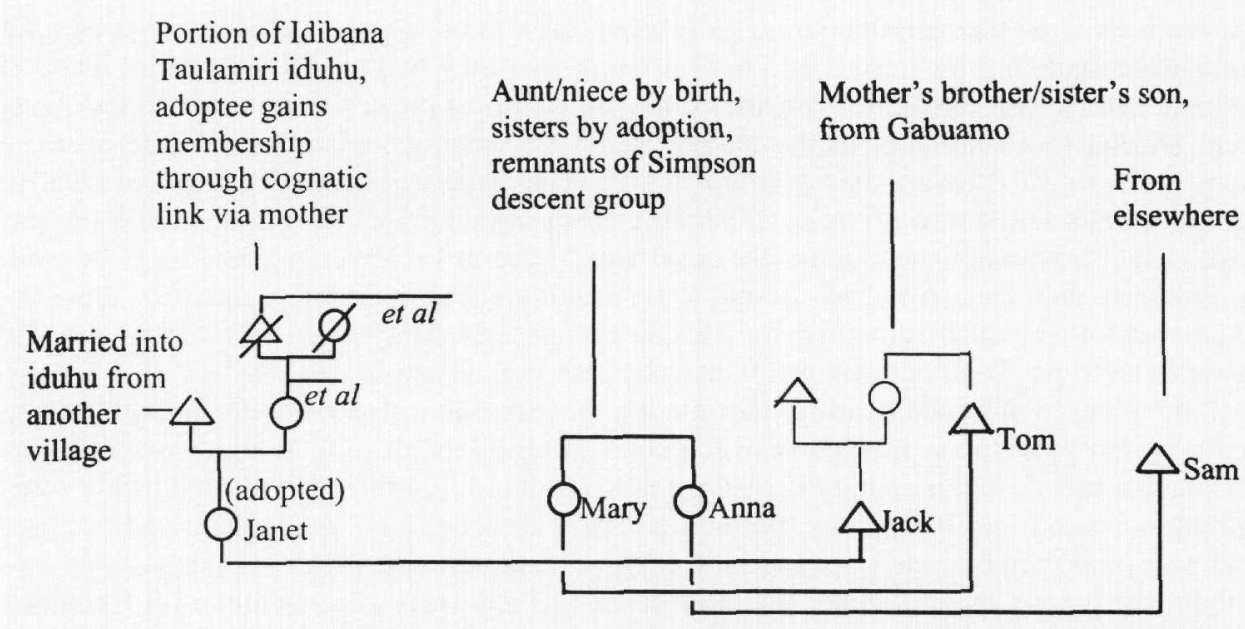

Figure 2. Mary, Anna and Janet from the original Simpson family, in Pari in 1999. All three have married non-Pari men who are living with them at Pari and have young children (not shown in diagram). Other members of the Simpson family shown in Figure 1 have either died or left the country.

child of one of them. When her Australian father left the country Anna was adopted by Paul Simpson himself (her biological grandfather) and became in effect Mary's younger sister. An older brother of Mary married a woman from Hanuabada whose brother was in turn married to a Pari woman. The marriage was shortlived, but shortly after its demise the woman gave birth to a child, Janet. Janet was adopted by the mother's brother, who had moved from Hanuabada and lived in Pari with his wife, who was a member of Idibana Taulamiri iduhu. Idibana Taulamiri was one of three iduhu resulting from the segmentation over time of Idibana (the others were Idibana Laurina and Idibana Rarua Mase ${ }^{13}$ ), and is acknowledged as the senior $i d u h u$ of the village since its core lineage descends agnatically from the founder of Pari. Janet's adoption meant that she became classified as a member of her adoptive mother's iduhu, Idibana Taulamiri, since her adoptive father was a village immigrant (see Fig.1). Her $i d u h u$ membership would prove to be a fateful distinction between herself and her biological father's sister (Mary) and father's sister's daughter (Anna). All three women married outside Pari village, Janet and Mary to two related men from Gabuamo and Anna to a man from elsewhere.

With the passage of time the males and some females in the Simpson family either died or moved to Australia. Left without male parents or brothers and married to outsiders, Mary and Anna had no claims to iduhu membership and no rights to land (see Fig.2). Having given them a place to live at Taurama beach, the tanobiaguna was pleased when Mary invited Janet and her husband (Mary's husband's sister's son) to live with them as Janet was a member of the tanobiaguna's own $i d u h u$ and consolidated, by occupation, ongoing iduhu control of that particular piece of land against other potential claimants. The subsequent falling out between Janet and the other women was disturbing in this regard since it was Janet, who had recognisable rights, who left. The tanobiaguna was thus faced with the diplomatic problem of what to do about Mary and Anna, who were there only with his permission, had no rights in relationship to the land they occupied, and had broken his stipulation that they should live in peace. He commented in discussions after the court case that he would probably have to ask them to leave. This eventuality had been the import of Janet's aside during the dispute hearing. However despite Janet's having said she would not return to reside with Mary and Anna, the women effected a reconciliation a few weeks after the case. They ritually slaughtered and consumed a pig, and appeared — for the time being at 
least - to have settled their differences, opening the way for Janet to return to the piece of land if she wished.

The case demonstrates the flexible criteria of $i d u h u$ membership, given the idiom of patrilineality at the centre of Motu discourses of descent. Janet became a member of an $i d u h u$ through adoption, indicating that biological kinship is not paramount, and the iduhu was that of her adoptive mother and mother's father, a cognatic link. But, importantly, the episode also indicates limits to flexible membership criteria. The original Simpson, who married a woman of Idibana iduhu more than a century ago, did not take up residence in Pari, or (as far as can be seen) take part in the sociality of the village. His son, Paul Simpson, was not recognised as a member of Idibana or any other iduhu when he brought his family to Pari. And residence in itself proved not to be adequate for his descendants Mary and Anna (who spent much of their childhood and adolescence in the village) to be classified as members of any iduhu. The lack of integration of the Simpson family with village iduhu through marriage meant that as their kin died or dispersed through marriage to nonvillage members Mary and Anna were left with no claims to land. Their own marriages, to outsiders, annulled any possibility that they could become attached to an iduhu and develop initial affinal connections to land. They were dependent on the goodwill of the tanobiaguna and latterly on repairing their relationship with Janet for their survival in the community. There seemed to be no animosity toward them in the discussions after the village court hearing or thereafter. Their lack of land was seen as the underlying problem and explained by their lack of $i d u h u$ membership. This, in turn, was blamed on the systemic disruption brought about by impermanent foreigners. The following case involves a village immigrant family of a different kind, and demonstrates other temporal and political aspects of the relationship between iduhu and land.

\section{THE GAEVA GAMU CASE}

A number of people from the Gulf Province live in Pari village and have intermarried with Motu-Koitabu villagers. Among them is a group descended from some families who migrated from Orokolo Bay in the 1920s and entered Pari village as clients of Kahanamona Idaro iduhu. Unlike the other Gulf migrants this group has maintained a group identity to the extent that it is identified as an iduhu, with the name Gaeva Gamu (combining the names of two proximate sites in Orokolo Bay), in the village. Nevertheless it has not fully assumed a Motu-Koitabu identity, and other villagers refer to it still as an iduhu 'of Gulf people.'

A village court case in 1999 involved an elderly man from Gaeva Gamu iduhu who wanted to build a house for himself and three sisters on a piece of land where he had gardens at the edge of the village. This brought him into dispute with a man of Vahoi iduhu, who said the land was his, handed down through his patrilineage. The old man had been allowed to develop gardens on the land by virtue of kinship with Vahoi iduhu initially established through a previous generation's marriage relations. His family's rights to use the land had been reaffirmed several times over a number of decades by negotiations with senior members of Vahoi and other interested parties. He claimed on the basis of his interpretation of these reaffirmations that his use rights extended to permanent residence. In the village court the Vahoi man responded to the Orokolo man's claims by reciting his own patrilineage through four ascending generations and claiming that as a boy he had been present at a meeting of interested parties which had permitted the continuation of Gaeva Gamu gardening but had made it clear that the land belonged unequivocally to Vahoi.

The Gaeva Gamu disputant had brought some elderly witnesses to the court to support his interpretation of the negotiated rights, but the hearing was effectively terminated when the Vahoi man said he had registered a claim on the area with the local land court. While this did not necessarily make the case at hand a land dispute under the terms of the Land Act, the village court magistrates immediately announced that they could not hear the mat- 
ter, in accordance with the Village Court Act. Having officially removed the village court from the burden of adjudicating, the magistrates informally recommended negotiations between interested parties (i.e. in the traditional way). One of them, an elderly man, commented that he had been a party to the negotiations at which the Vahoi man had been present and suggested (without going into detail) that the Vahoi man had been too young to fully understand the subtleties of the negotiations. But the Vahoi man pointed out that he had firm plans for this piece of land and his unquestionable patrilineal genealogy - which he saw as proof of his ownership in respect of the claim with the land court - left nothing to negotiate, so far as he was concerned.

The village court usually tried to achieve reconciliation between disputants in its hearings, and the blunt intransigence of the Vahoi man created potential difficulties for a resolution in this case. The speed with which the magistrates washed their hands of the affair at the mention of the land court (without the Vahoi man elaborating the nature or purpose of the claim) suggests their claim that the case was beyond their jurisdiction may have been expedient rather than strictly judicial. They commented to me afterwards that they preferred that disputes of this nature were settled by negotiation between all interested parties, rather than by a court decision. In Pari and other village courts 'decisions' are often a reflection of community opinions of what the outcome of a dispute should be, and serve as an official stamp on the common sense of what is pragmatic in the interests of the community at large, rather than as an adjudication of an issue exclusive to the two parties. In this respect landright disputes are particularly onerous for village courts, because long histories of negotiated multiple claims on a given piece of land mean that many people are likely to be affected one way or another by what may superficially appear to be a dispute between only two individuals.

Other considerations may have played a part in the Vahoi man's attitudes, too. Another villager pointed out to me that if the Gaeva Gamu man had been a person of high social status, the Vahoi man would probably have been more agreeable to allowing him residential status. This was an allusion to the dynamics of reciprocation in Papua New Guinea societies in general. A more socially or politically prominent person would have offered the potential of reciprocation, to the landholder's advantage, for being allowed residence (the Prime Minister of the time, Bill Skate, had married a Pari woman, and was quickly given residential land on a hillside near the village). To this was added a reminiscence that the Gaeva Gamu man had been an aggressive character in his younger days, implying that community perception of his past behaviour may have had a bearing on responses to his present claim.

The case indicates the tradition of negotiated land rights and the equivocation which is engendered by such a process, inasmuch as the Gaeva Gamu man was mooting a residential right superceding an original gardening right. He based this on his having used the land for several decades, and regarded a succession of negotiations reaffirming his use rights as a process strengthening his land-holding. At the same time, the idiom of patrilineality, as a first principle, is demonstrated by the Vahoi disputant's genealogical argument. Until recently, as the suggestions of the magistrates after the termination of the hearing indicated, such a dispute would have been resolved by the involvement of elders in negotiations, and as a further resort if necessary a tanobiaguna could have arbitrated. Through this process the Vahoi disputant may have been obliged to temper his intransigence under the pressure of elders. A tenuity in the status of Gaeva Gamu iduhu in Pari is suggested here, too. Its identity has not been lost by the dispersal of its members into other iduhu, but at the same time it is an iduhu of non-Motu-Koitabu in the perception of other villagers, and while it is not significantly marginalised it is dependent on periodic renegotiation and goodwill for its access to land.

The Vahoi disputant's reference to the local land court introduces another, modern, complication to the relationship between iduhu and land. The local land courts were introduced by legislation, the Land Disputes Settlement Act, at the end of the colonial period. 
Like the village courts, they were enjoined to follow custom, rather than common law, and to achieve settlement by mediated negotiation rather than by adversarial process, and without the involvement of lawyers. But, also like the village courts, they were situated in the hierarchical structure of the colonially introduced Anglo-Australian legal system, permitting appeals to, and intervention by, higher courts. As Zorn has pointed out, this means that in the practical operation of the land court system there can be a difficult engagement between customary procedure and common law (Zorn 1992:14-33). As with the village courts, the exigencies of structural involvement in a state legal system impose a formality on local land courts which was not historically intended. While the land court officials can investigate the wider historical and social context of a land dispute and be sensitive to local customs and idiosyncrasies, appeals to higher courts often result in the imposition of decisions based on common law. In practical terms this amounts to cumulative pressure for a more systematic and precedent-based approach in the land courts (Zorn 1992). Ironically the appeals which generate this pressure arise from a common refusal in Papua New Guinea societies by disputants over land to recognise legal or quasi-legal decisions as final or representing closure of an issue, as Zorn has noted (Zorn 1992:29). This, in turn, results from the dynamics manifest in constant renegotiations over land use within communities, as the discussion in the latter part of this article has shown. Time will tell whether local land courts become more formal procedurally and less flexible in recognition of the political and temporal vagaries of local customs under the pressure of a structurally dominant common law approach.

The involvement of a local land court in disputes such as the Gaeva Gamu case casts a shadow on the future possibility of negotiations of the kind which appear to have typified land matters in Pari in the past. The Vahoi man's appeal to patrilineality as an over-riding principle could be portentous, for example, if recourse to the local land court, rather than traditional negotiation, becomes a trend and if the land court for its part shifts toward a common law interpretation of its work. In such a (hypothetical) circumstance patrilineality, currently an idiomatic first principle used when defining iduhu and a strong argumentative position in land-right negotiations, could conceivably be transformed into a rule governing land rights. Not only would this dramatically change the flexible nature of negotiated landrights, but it could also affect the way people think about $i d u h u$ membership.

\section{CONCLUSIONS}

Representations of the cultural history of Pari village commonly focus on the patriarchal culture hero Kevau Dagora and the mother of tuna Ugata Vaina - the former inaugurating the growth of the village (Pulsford and Heni 1968, Oram 1968:83-85, 1981:211,226) and the latter chartering a moral identity which was transformed by Christianity and the cash economy (cf. Ikupu 1930, Egi 1963, Gebai 1973, Kidu 1976, Pulsford 1975). But we can discern a material history, too, in which access to land is central. The land was originally apportioned by Kevau Dagora, and land rights were negotiated as new iduhu arrived. The shift of housing onto the land after the Second World War possibly increased the complexity of those multiple negotiated land rights. In the Gaeva Gamu case a quasi-iduhu of foreigners is still attempting to consolidate land holdings after three-quarters of a century, and an elderly man, latterly denied the traditional potential of negotiation, is unable to establish a house on land he has been using for many years. And the Simpson case indicates that those who lack iduhu membership by any flexible criteria and are unable to establish and maintain land rights find survival in the village tenuous. In the light of this, Diritala's description of an iduhu as 'the largest body of people who may interest themselves in a piece of land as a whole' (Diritala 1976:58), while inadequate in representing the social character of the unit, seems a reasonable material premise.

But while a fundamental material concern of $i d u h u$ is land the idiom of patrilineality, so commonly breached in recruitment practice, appears to be a significant component of 
their historical identity and in this respect the iduhu kwarana is focal. Since individuals may become iduhu members through a number of means other than patrifiliation, the iduhu kwarana is not so much a central figure to whom individual iduhu members relate themselves through agnatic ties as he is the embodiment of an idiomatic genealogy of the iduhu as a whole to which recruits by various means commit themselves. A century and a quarter after missionary contact, his incarnation of the $i d u h u$ is no longer tangibly expressed in the facilitation of feasts and dancing, which perhaps diminishes his prospects of achieving a certain type of renown. But the iduhu kwarana, however politically or ceremonially inactive, cannot be replaced by new lohia. Church leaders, politicians, and other new big-men cannot incarnate an $i d u h u$, because unlike the kwarana they are not idiomatically intrinsic to its identity.

Considering the kwarana-focussed historical identity together with the chronic preoccupation with access to land, it seems to me that major social and cultural transformations such as the disappearance of traditional dancing, feasts, and other activities under the influence of Christianity, colonialism and the cash economy, have not actually undermined the 'structure' of $i d u h u$, inasmuch as the two principal characteristics of $i d u h u$, the material and the idiomatic, have been unaffected by these disappearances. In Pari village, as much affected by missionary pressure as any other Motu-Koitabu village, iduhu have doubled in number since Seligman's 1904 visit despite the toll of the Second World War evacuation. This has come about not from the structurally redintegrative activities of church leaders, but as a result of immigration and fissions triggered, for example, by the same fraternal antagonisms and land disputes typifying the classical dynamics of iduhu development (cf. Goava 1979a, Oram 1981). As the recruitment criteria of $i d u h u$ are flexible enough to allow membership through cognatic and affinal links to a significant extent, landholding rights are chronically a matter of negotiation as new and potential members attempt to consolidate their attachment to $i d u h u$ land: historically $i d u h u$, as social units, have not been structurally totalised by a clear coincidence of rules of descent with rules of landholding. It is possible, then, that an increased use of local land courts, which may be drawn into a common law-oriented legal structure (Zorn 1992), could affect the social makeup of iduhu if the principle of patrilineality became institutionalised as a rule in respect to landholding. More generally, I believe fundamental changes to the nature of $i d u h u$ would be brought about by land loss, of the kind now expressly feared by the Motu-Koitabu in general and especially by those in the Hanuabada village complex.

\section{ACKNOWLEDGMENTS}

I am grateful to the National Research Institute of Papua New Guinea for the affiliation status which made my 1999 fieldwork visit possible, to the Village Court Secretary, Mr Peni Keris, for co-operation for several years now, and to Mr Andrew Kadeullo for his encyclopaedic knowledge of village courts and general research assistance. In Pari I received valuable advice and assistance from the village court magistrates, Messrs Gaba Gaudi, Sisia Baeau, Puka Vagi, Oala Igo, Morea Hekoi and Lohia Daure, and the court clerk Mr Sibona Gaudi. Lengthy discussions with Lady Carol Kidu, Mr Gaudi Kidu, and Professor Isi Kevau helped clarify my understanding of local history and social organisation. Nigel Oram commented usefully on an early draft.

\section{NOTES}

1. The story of the destruction of Taurama, the founding of Pari and the origin of the village's name was told me by several older men of Pari village in 1994, and again in 1999, during which I was shown the putative site of Kevau Dagora's dwelling, on which now stands a house occupied by his patrilineal descendants. These versions were consistent with the accounts given in academic articles such as those by Oram (1968, 1981) and Pulsford and Heni (1968). It is possible that in recent decades oral historical accounts among the Western 
Motu have been influenced by a number of academic researchers: at any rate there is now a locally unequivocal version of the establishment of Pari village.

2. I have found nothing to support Rosenstiel's contention (1953:31-32) that Motu practised cross-cousin marriage. Seligman recognised that marriage could occur within an iduhu, and described the exogamy rule as extending to 'third cousins' (Seligman 1910:82).

3. Diritala, too, gets into difficulty with anthropological concepts: his employment of 'clan' and 'lineage' is ambiguous, and at one point he inexplicably refers to a 'matrilineage' (Diritala 1976:58-59).

4. What Turner heard as 'lohiapata' (see above) was most likely lohiabada: bada meaning 'big' whereas pata means 'table', or 'platform', though it should be noted that when ceremonial platforms were built they were symbolically connected to specific iduhu leaders (Seligman 1910). Lohiabada was a term adopted later by the colonial administration when appointing a senior 'chief' to represent the Motu in general. In Motu Christian discourse it is used in reference to Jesus, serving as a translation of 'Lord'.

5. Researchers in the past have opted for 'top man', since the Motu noun dori translates as 'top', but I am unconvinced of the appropriateness of this gloss.

6. I should cautiously acknowledge that a sorcerer (vadari tauna/hahine [male/fem] or mea tauna/hahine) might also enjoy 'high', though morally ambivalent, status. Sorcery is a difficult topic in the current discursive context, since account needs to be taken of distinctions between, for example, publicly recognised and privately suspected sorcerers, among other matters of identification. Also, the English term 'sorcery' is commonly used to gloss a complex variety of activities, both good and evil, including those of a diviner (babalau tauna/hahine). Thus I cannot include 'sorcerers', as a simply definable category of prominent people, in my discussion.

7. Interestingly, in a discussion of the Mekeo, a Papuan group speaking an Austronesian language with some similarities to Motu, Stephen critiques longstanding translations of the term lopia, used of Mekeo leaders. In preference to 'chief' which she says is misleading and 'implies a functional, political role that is largely inappropriate in this cultural context', she offers 'man of kindness' (Stephen 1995:24), drawing on a secondary meaning given in a Mekeo-French dictionary compiled in the 1920s and 1930s by a missionary.

8. Seligman's published plan is upside down, inasmuch as its orienting compass, supposedly indicating north, is pointing out to sea, to what is in fact the south. This gives the unfortunate impression, contrary to Seligman's description of Motu-Koitabu village organisation, that the houses were at the time built on the land and ceremonial platforms built in the water.

9. Tarr (1973) reports Pari villagers being moved to a site to the east, near the Eastern Motu village of Gaire and known as 'New Pari'. There is an implication in a more general account of Motu villagers in wartime by Robinson that some Pari villagers were evacuated to Manumanu, west of Port Moresby (Robinson 1979). All the older people I consulted at Pari gave 'New Pari' as the evacuation location.

10. 1990 National Population Census, Final Figures, Census Unit Populations, National Capital District, p6. National Statistical Office, 1993. The Census unit should be treated cautiously, compared to village head counts by previous researchers, as it covers a wider area than the circumscribed village and possibly contains peri-urban settlers who cannot be regarded as Pari villagers or their land-clients.

11. In addition to this representation I have orally been offered Iguta, Igutu and Uguta. For convenience I am using Pulsford's (1975) spelling.

12. Village court officials in Pari have always emphasised to me that disputes in the court are public and that I am at liberty to name people and give full details of all cases. Nevertheless, in view of the substance of this dispute and its background I thought it prudent to change the names of all those involved, for readership beyond the village. They will be instantly identifiable by Pari villagers, to whom all the information given herein is familiar.

13. In 1995-6 a new iduhu, Idibana Etau Laio, was created when some lineages broke away from Idibana Taulamiri.

\section{REFERENCES}

BARNES, J.A. 1966. African Models In The New Guinea Highlands. Ian Hogbin and L.R.Hiatt (eds) Readings In Australian And Pacific Anthropology, pp.117-129. Melbourne: Melbourne University Press.

BELSHAW, Cyril.1957. The Great Village. London: Routledge and Kegan Paul.

BULMER, Susan. 1971. Prehistoric settlement patterns and pottery in the Port Moresby area. Journal of the Papua and New Guinea Society. 5(2):29-91.

1982. West of Bootless Inlet: archaeological evidence for prehistoric trade in the Port Moresby area and the origins of the hiri. Tom Dutton (ed.) The Hiri in History: Further aspects of long distance Motu trade in Central Papua, pp. 117-130. Canberra, Australian National University. Pacific Research Monograph No.8.

DIRITALA, Lucius. 1976. Genealogies and customary land tenure. Administration For Development. No.7:56-68.

DOUGLAS, Bronwen. 1979. Rank, Power, Authority: a Reassessment of Traditional Leadership in South Pacific Societies. The Journal of Pacific History 14:2-27.

DUTTON, Tom. 1982. Towards a history of the hiri: some beginning linguistic observations. Tom Dutton (ed) The 
Hiri in History: Further aspects of long distance Motu trade in Central Papua, pp.65-98. Canberra: Australian National University. Pacific Research Monograph No 8.

1985. Police Motu: Iena Sivarai. Waigani: University of Papua New Guinea Press.

EARLE, Timothy. 1997. How Chiefs Come to Power. California: Stanford University Press.

EGI, Lahui Tau. 1963. The tale of five tuna fish. Australian Territories 3(5):16-19.

FILER, Colin. 1994. News from nowhere: Leadership in spades. Research in Melanesia 18:85-92.

1995. News from nowhere: More chiefs in the making. Research in Melanesia 19:19-21.

FOX, Robin. 1976. Kinship And Marriage. Middlesex: Penguin.

GEBAI, Allen M. 1973. How the people of Pari have come to believe strongly that the tuna fish comes originally from the human family. Mark Arek (comp) Eleven Long Legends, pp.23-24.Goroka: Goroka Teachers College.

GOAVA, S. 1979a. Kori Taboro's story. Oral History 7(3):65-94.

1979b. Kori Taboro ena sivarai. Oral History 7(3):95-123.

GOAVA, Sinaka and George WRONDIMI. 1986. The Motu-Koitabu people of Hanuabada and their customary land in the past, the present and the future: A pilot study. Port Moresby: National Capital District Interim Commission Occasional Research Paper No 1.

GOLDMAN, Irving. 1970. Ancient Polynesian Society. Chicago: University of Chicago Press.

GOLSON, J. 1968. Introduction to Taurama Archaeological Site Kirra Beach. The Journal of the Papua and New Guinea Society, 2(2):67-71.

GREGORY, C.A. 1980. Gifts to men and gifts to god: Gift exchange and capital accumulation in contemporary Papua. Man, 15(4):626-652.

1982. Gifts and Commodities. London: Academic Press.

GROVES, Murray. 1954. Dancing in Poreporena. Joumal of the Royal Anthropological Institute of Great Britain and Ireland $84: 75-90$.

1963. Western Motu Descent Groups. Ethnology 2(1):15-13.

HANSON, Allan. 1989. The Making of the Maori: Culture Invention and its Logic. American Anthropologist 91:890-902.

HITCHCOCK, Nancy and Nigel ORAM. 1967. Rabia Camp: A Port Moresby migrant settlement, Canberra: Australian National University, New Guinea Research Bulletin No.14.

HOGBIN, Ian and Peter LAWRENCE. 1967. Studies in New Guinea Land Tenure, Sydney: Sydney University Press.

HOLY, Ladislav. 1996. Anthropological Perspectives On Kinship. London: Pluto Press.

IKUPU, Ovia. 1930. Story about Kidukidu. Papuan Villager 2(12):7.

JOKU, Harlyne. 1999. Landowners to wage war against port relocation. The National Online, http://www.wr.com.au/national/991207t7.htm.

KEESING, Roger M. 1975. Kin Groups And Social Structure. New York: Holt, Rinehart and Winston. KIDU, B. 1976. The Kidu of Pari. Oral History 4(2):92-97.

KIDU, Lady Carol. 1999. Need to halt menace of illegal settlements. The National Online, http://www.wr.com.au/national/99121603.htm.

LINDSTROM, Lamont and Geoffrey M.WHITE. 1997. Introduction: Chiefs Today. Geoffrey M.White and Lamont Lindstrom (eds) Chiefs Today: Traditional Pacific Leadership and the Post-Colonial State. California: Stanford University Press.

MADDOCKS, D.L. and I. MADDOCKS. 1972. Pari Village Study: Results and Prospects

1971. PNG Medical Journal 15(4):225-233.

1977. The Health of Young Adults in Pari Village. PNG Medical Journal 20(3):110-116.

MADDOCKS, I. 1971. Udumu A-Hagaia. Waigani: University of PNG, Inaugural lecture.

MADDOCKS, I., D.MADDOCKS, K.KEVAU, J.MacKAY, Q.GAUDI, M.HURUVARI. 1974. Pari Hanua Ruma Ai Lada-Torena. Waigani: University of PNG.

NORWOOD, Hugh. 1984. Port Moresby: Urban villages and squatter settlements. Port Moresby: University of Papua New Guinea Press.

ORAM, N.D. 1968. Taurama æ Oral Sources For A Study Of Recent Motuan Prehistory. The Journal of the Papua and New Guinea Society 2(2):79-91.

1976. Colonial Town to Melanesian City. Canberra: Australian National University Press.

1981. The History of the Motu-speaking and Koitabu-speaking Peoples according to their own Traditions. Donald Denoon and Roderic Lacey (eds) Oral Tradition in Melanesia, pp.207-229. Port Moresby: University of PNG and Institute of PNG Studies.

1982. Pots for sago: the hiri trading network. Tom Dutton (ed.) The Hiri in History: Further aspects of long distance Motu trade in Central Papua, pp.1-33. Canberra: Australian National University, Pacific Research Monograph No 8.

1989. The Western Motu area and the European impact: 1872-1942. Sione Latukefu (ed.) Papua New Guinea: A Century of Colonial Impact 1884-1984, Port Moresby: National Research Institute and University of Papua New Guinea.

PULSFORD, R.L. 1975. Ceremonial Fishing for Tuna by the Motu of Pari. Oceania 46(2): 107-113.

PULSFORD, R.L. and V.HENI. 1968. The Story of Taurama Village As Told By Aire Aire Rahobada of Pari Village. The Journal of the Papua and New Guinea Society 2(2):97-100. 
RADCLIFFE-BROWN, A.R. 1967. Introduction. A.R.Radcliffe-Brown and Daryll Forde (eds) African Systems Of Kinship And Marriage, pp.1-85. London: Oxford University Press.

RADCLIFFE-BROWN, A.R. and Daryll FORDE (eds). 1967. African Systems Of Kinship And Marriage. London: Oxford University Press.

ROBINSON, Neville K. 1979. Villagers At War: some Papua New Guinean experiences in World War II, Canberra: Australian National University, Pacific Research Monograph No 2.

ROSENSTIEL, Annette. 1953. The Motu of Papua New Guinea: A study of successful acculturation. Columbia Unversity, PhD Thesis.

SACK. Peter G. 1973. Land Between Two Laws: Early European Land Aquisitions in New Guinea, Canberra: Australian National University Press.

SCHNEIDER, David M. 1984. A Critique of the Study of Kinship. Michigan: University of Michigan Press.

SEFALA, Alex 1999. Report recommends setting up of Motu-Koita panel. The National Online, http://www.wr.com.au/national/991212n5.htm.

SELIGMAN, C.G. 1910. The Melanesians of British New Guinea. Cambridge: Cambridge University Press.

STEPHEN, Michele. 1995. A'aisa's Gifts: A study of magic and the self. Berkeley: University of California Press. TARR, Jim. 1973. Vabukori and Pari - the years of war. Oral History 1(7):13-22.

TAU, Nou. 1978. Land tenure in Hanuabada. Administration For Development. No.11:72-85.

TURNER, James West. 1997. Continuity and Constraint: Reconstructing the Concept of Tradition from a Pacific Perspective. The Contemporary Pacific 9(2):345-381.

TURNER, W.Y. 1877. The Ethnology of the Motu. University of Glasow, M.D.Thesis.

WHITE, Geoffrey M. 1992. The Discourse of Chiefs. The Contemporary Pacific 4(1):73-108.

WHITE, Geoffrey M. and Lamont LINDSTROM (eds). 1997. Chiefs Today: Traditional Pacific Leadership and the Post-Colonial State. California: Stanford University Press.

WOLF, Eric R. 1982. Europe And The People Without History. Berkeley: California University Press.

ZORN, Jean G. 1992. Graun Bilong Mipela: Local Land Courts and the Changing Customary Law of Papua New Guinea. Pacific Studies. 15(2):1-38 